\title{
Diversity patterns of fauna in dripping water of caves from Transylvania
}

\author{
Ioana N. Meleg ${ }^{1}$, Oana T. Moldovan ${ }^{1 *}$, Sanda Iepure ${ }^{1}$, Frank Fiers ${ }^{2}$ and Traian Brad ${ }^{1}$ \\ 1 “Emil Racoviţă” Institute of Speleology, Department of Cluj, Romanian Academy, Clinicilor 5, PO Box 58, 400006 Cluj-Napoca, \\ Romania \\ 2 Royal Belgian Institute of Natural Sciences, Vautierstraat 29, B-1000 Brussels, Belgium
}

Received 12 July 2010; Accepted 4 January 2011

\begin{abstract}
Recent studies substantiate the importance of the unsaturated zone in ground-water biodiversity of karst areas. Few investigations, however, have addressed the temporal changes in community composition in relation to water physico-chemical features. We provide information on the distribution pattern of the fauna in dripping water at spatial and temporal scales. This is related to variation in water chemistry and other environmental features in five caves within two hydrographic basins of the Pădurea Craiului Mountains (northwestern Romania). The analysis revealed no major pollution in the dripping water. The physicochemical parameters varied within and between caves over one year. The dripping water fauna is heterogeneously distributed within and between the caves, containing a mixture of epigean and hypogean species. This emphasizes high microhabitat partition and also underlines the influence of physico-chemical parameters. The species composition among the two hydrographic basins was different. Crustaceans are the best represented in terms of both abundance and species richness. Six out of 15 crustacean species are endemic to the Pădurea Craiului Mountains and four are new to science. All these point to the importance of unsaturated karstic habitats as biodiversity hot spots in ground-water ecosystems.
\end{abstract}

Key words: Biodiversity / karst unsaturated zone / Pădurea Craiului Mountains / Romania

\section{Introduction}

The epikarst is the uppermost unsaturated zone of carbonate rocks. It extends several meters underground and is characterized by high porosity and permeability, potentially containing large water reserves (Mangin, 1994). Water infiltrating from the surface or from the soil percolates through the epikarst before reaching the vadose zone. It then continues downward and reaches the saturated or phreatic zone of caves (Jones et al., 2004).

Despite an apparent scarcity, the fauna inhabiting the fissures and cracks of the unsaturated zone (epikarst and vadose zone) is diverse and often exceeds the diversity of other habitats such as pools, subterranean streams or lakes (Juberthie, 2000; Pipan and Brancelj, 2004a; Galassi et al., 2009). This high diversity, combined with the presence of a mixture of soil, epikarstic and typical hypogean fauna, makes the study of the upper layer of the karst highly interesting for biologists (Pipan and Culver, 2007a).

\footnotetext{
*Corresponding author: oanamol@hasdeu.ubbcluj .ro
}

The fauna inhabiting the water in fissures first came to the attention of Bou (1979), Delay (1968) and Rouch (1968), who sampled the dripping water from stalactites and the temporary water flowing on cave walls. Recently, the unsaturated zone has been extensively investigated at different scales, revealing a high biodiversity associated with a high degree of endemism, mainly among crustacean copepods (Pipan and Brancelj, 2001, 2004a, 2004b; Brancelj, 2002; Bobić, 2003; Sket et al., 2004; Pipan, 2005; Pipan and Culver, 2005, 2007a, 2007b, 2007c; Moldovan et al., 2007; Pipan et al., 2008). All studies emphasized the heterogeneity of the faunal distribution in the unsaturated zone. Some demonstrated that the faunal composition is influenced by certain abiotic features of the ecosystem, mainly temperature, electrical conductivity, precipitation and thickness of the cave ceiling.

This contribution provides an overview of the aquatic communities in dripping water of several caves by investigating the $\alpha$-diversity (within caves) and the $\beta$-diversity (between caves) in the regional context of the Romanian Western Carpathians. This is coupled with an attempt to define spatial and temporal patterns of 


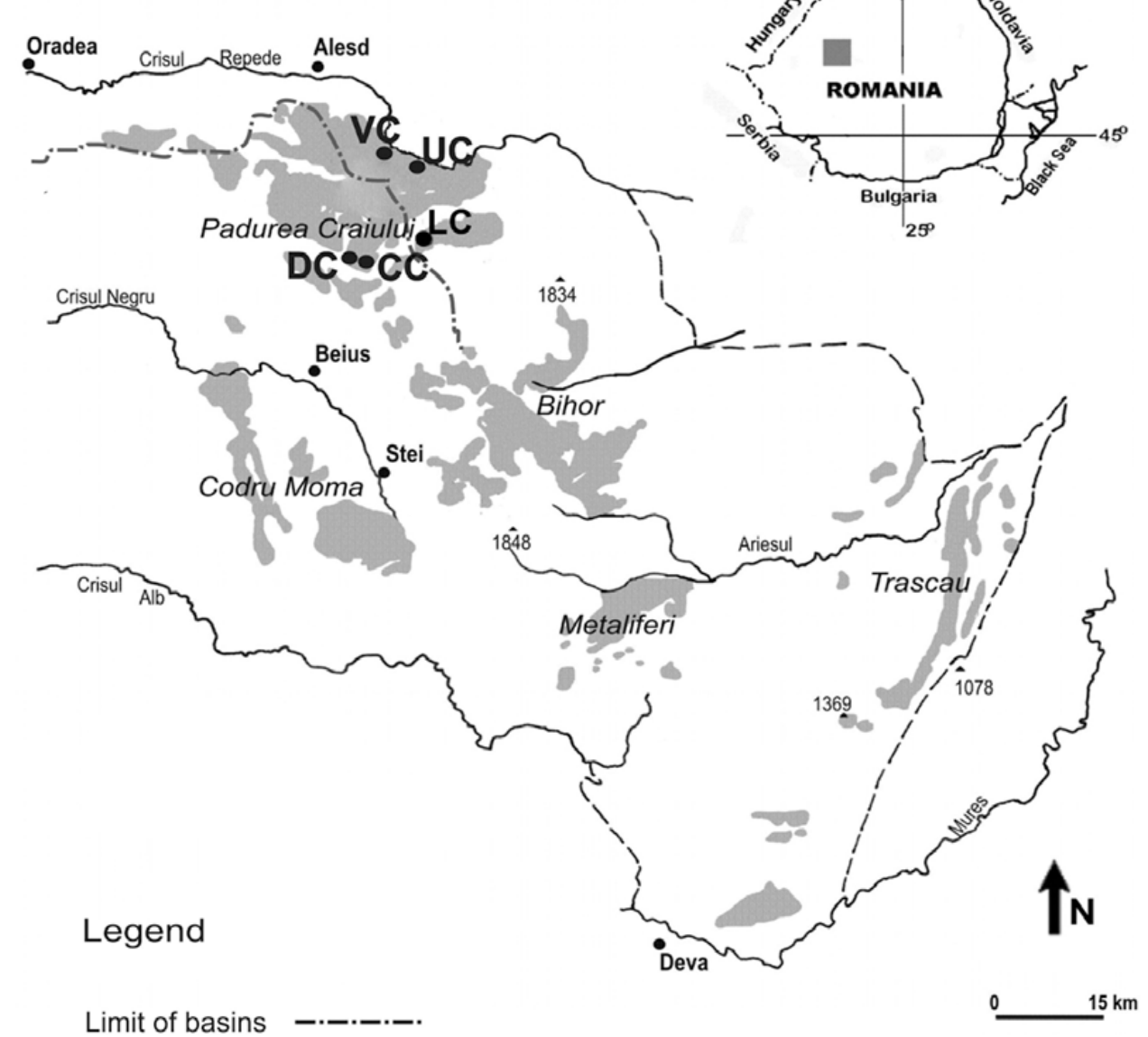

Fig. 1. Locations of investigated caves in the Pădurea Craiului Mountains (northwestern Romania): grey surfaces are limestone areas (for abbreviations see Table 1).

distribution and abundance of subterranean communities in relation to environmental parameters.

\section{Materials and methods}

\section{Study area}

The spatial and temporal dynamics of the fauna at micro- (within-cave, ranging from 3 to $500 \mathrm{~m}$ ) and mesoscales (part of river basins, ranging from 1 to $15 \mathrm{~km}$ ) were analyzed in the Pădurea Craiului Mountains, located in the western part of the Carpathian ridge in Romania (the Apuseni Mountains). The massif is mainly composed of Mesozoic sediments, whereby the karst landscape is highly represented, up to $37 \%$ of the entire surface (Rusu, 1988).

Our study focused on five active caves (Fig. 1) of different lengths (320-4000 m) within a range of approximately $200 \mathrm{~km}^{2}$ between the catchment areas of two hydrographic basins: Crişul Repede (three caves) and Crişul Negru (two caves). Details on the geographical position of the caves, the sampling periods, the number of sites in each cave and the total number of collected samples are given in Table 1 and Figure 2. Ungurului Cave (UC) is developed in Ladinian (middle Triassic) limestone and Vadu Crişului Cave (VC) in Barremian (Cretaceous) limestone (Orăşeanu, 1991). The entire area has been intensively exploited for fireclay. Ciur Izbuc Cave (CC), developed on two levels, and Doboş Cave (DC) are located on the karstic plateau of Runcuri. These two caves, together with the Cave cu Apă din Valea Leşului (LC), have developed in Neocomian-lower Aptian (lower Cretaceous) limestone (Orăşeanu, 1991). Two household deposits are located above DC, and the wastewater enters the cave downstream of the selected sampling sites. The area was intensively exploited for bauxite and for fireclay with iron and aluminum oxides.

\section{Sampling protocol}

Preliminary investigations were conducted in the selected caves in order to identify the permanent or quasi-permanent character of the drips. Fauna and water samples were taken monthly from January to December 2008, with the exception of one cave (Table 1). Samples omitted due to external weather conditions (i.e., frozen or dry periods, high water levels) are specified in Table 1. The water from trickles was directed through a funnel 
Table 1. Investigated caves from the Pădurea Craiului Mountains (northwestern Romania) (see also Figs. 1 and 2).

\begin{tabular}{|c|c|c|c|c|c|c|c|c|c|}
\hline Cave & Abbrev. & Basin & $\begin{array}{l}\text { Altitude } \\
\text { (m above } \\
\text { sea level) }\end{array}$ & $\begin{array}{l}\text { Geographic } \\
\text { coordinates }\end{array}$ & $\begin{array}{l}\text { Length } \\
(\mathrm{m})\end{array}$ & $\begin{array}{c}\text { Sampling } \\
\text { period }\end{array}$ & $\begin{array}{c}\text { Number } \\
\text { of sites }\end{array}$ & $\begin{array}{c}\text { Total } \\
\text { number of } \\
\text { samples } \\
\text { collected }\end{array}$ & $\begin{array}{c}\text { Samples } \\
\text { not collected }\end{array}$ \\
\hline Ungurului Cave & $\mathrm{UC}$ & $\begin{array}{l}\text { Crişul } \\
\text { Repede }\end{array}$ & 305 & 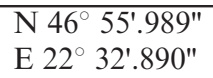 & 1500 & I-XII 2008 & 3 & 31 & Site 1 in I, II, III, IX, X \\
\hline $\begin{array}{l}\text { Vadu Crişului } \\
\text { Cave }\end{array}$ & $\mathrm{VC}$ & $\begin{array}{l}\text { Crişul } \\
\text { Repede }\end{array}$ & 305 & $\begin{array}{l}\text { N } 46^{\circ} 57^{\prime} .714^{\prime \prime} \\
\text { E } 22^{\circ} 30^{\prime} .679^{\prime \prime}\end{array}$ & 4000 & I-XII 2008 & 9 & 105 & $\begin{array}{l}\text { Site } 2 \text { in XI } \\
\text { Site } 9 \text { in III, IV, XI }\end{array}$ \\
\hline $\begin{array}{l}\text { Cave cu Apă din } \\
\text { Valea Leşului }\end{array}$ & $\mathrm{LC}$ & $\begin{array}{l}\text { Crişul } \\
\text { Repede }\end{array}$ & 650 & $\begin{array}{l}\text { N } 46^{\circ} 49^{\prime} .528^{\prime \prime} \\
\text { E } 22^{\circ} 33^{\prime} .419^{\prime \prime}\end{array}$ & 800 & I-XII 2008 & 6 & 71 & \\
\hline Ciur Izbuc Cave & $\mathrm{CC}$ & $\begin{array}{l}\text { Crişul } \\
\text { Negru }\end{array}$ & 395 & $\begin{array}{l}\mathrm{N} 46^{\circ} 51^{\prime} .100^{\prime \prime} \\
\mathrm{E} 22^{\circ} 24^{\prime} .002^{\prime \prime}\end{array}$ & 1030 & I-XII 2008 & 9 & 98 & \\
\hline Doboş Cave & DC & $\begin{array}{l}\text { Crişul } \\
\text { Negru }\end{array}$ & 467 & $\begin{array}{l}\text { N } 46^{\circ} 50^{\prime} .658^{\prime \prime} \\
\text { E } 22^{\circ} 23^{\prime} .584^{\prime \prime}\end{array}$ & 320 & $\begin{array}{l}\text { III } 2008- \\
\text { II } 2009\end{array}$ & 4 & 45 & Site 4 in IX, $X$ \\
\hline
\end{tabular}
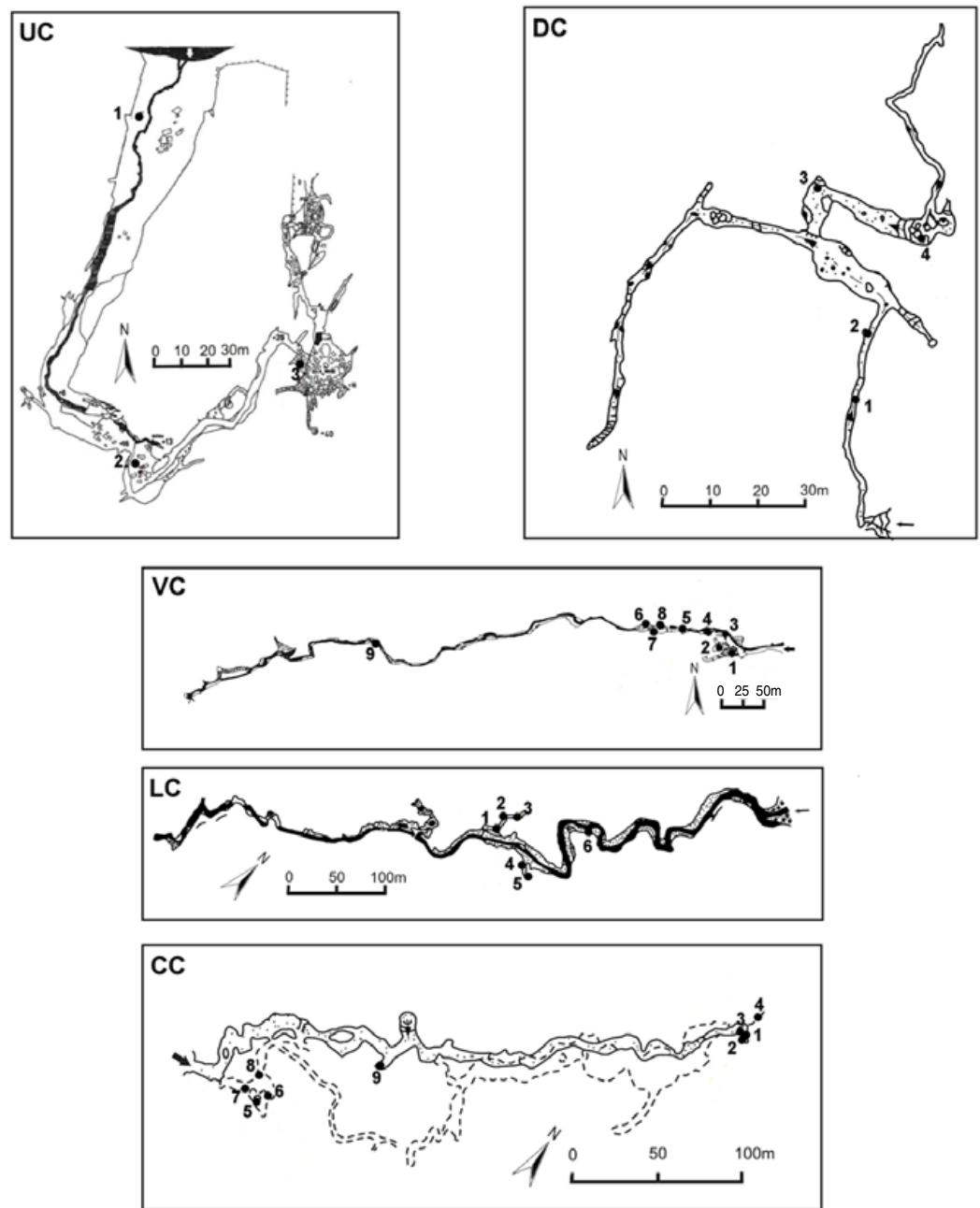

Fig. 2. Cave maps and sampling site position (UC map - modified from Vălenaş and Iurkiewicz, 1981; VC map - modified from Pleşa, 1969; LC, CC, DC - modified from Rusu, 1988).

into containers whose sides were covered by a $100 \mu \mathrm{m}$ mesh plankton net, following the protocol described and utilized by Pipan and Brancelj (2001, 2003). Animals were able to survive for one month in the $1 \mathrm{~cm}$ deep water at the bottom of the container. Animals were fixed in $96 \%$ ethanol and sorted to different taxonomic levels using a stereomicroscope (Olympus SZX16): phylum (Nematoda), class or subclass (Gastropoda, Oligochaeta), infraclass (Acarina), order (Collembola) and family (Chironomidae). Crustaceans were identified to species level under an Olympus BX51 microscope. Collembolans and isopods were removed from the 
statistical analyses because the identified species proved to be terrestrial or semiterrestrial, not aquatic.

Physico-chemical parameters $(\mathrm{pH}$, electrical conductivity (EC) $\left(\mu \mathrm{S} . \mathrm{cm}^{-1}\right)$ and temperature $\left.(T)\left({ }^{\circ} \mathrm{C}\right)\right)$ were measured on-site using a portable HANNA Combo, HI 98129 instrument. Chemical analyses of the drip water in caves UC, VC and CC were performed at the Research Institute for Analytical Instrumentation (Cluj-Napoca): dissolved metals (Al, $\mathrm{Cr}, \mathrm{Fe}$ ) with an inductively coupled mass spectrometer Perkin Elmer, ELAN DRC II; $\mathrm{NO}_{2}^{-}$ with an ion chromatograph 761 Compact Metrohm; and chemical oxygen consumption (COD) by potassium permanganate titration in acid medium.

Dripping water contamination was established by comparing the results with the standard limits established by the Romanian and European Standards for drinking water quality.

\section{Statistical analyses}

Multivariate analyses were performed using the software XLSTAT Version 2010 (Addinsoft SARL). Samples with less than three individuals were excluded from the data set. To visualize the relationship between the identified taxa and physico-chemical parameters, Canonical Correspondence Analyses (CCA) were computed.

The sampling effort was tested by constructing a species accumulation curve (SAC) based on the MaoTau procedure (Colwell et al., 2004) and computed with EstimateS version 7.5 (Colwell, 2005).

$\alpha$-Diversity was calculated as the diversity of the crustacean community associated with each cave using the Shannon-Wiener index $(H)$. $\beta$-Diversity was analyzed by comparing species richness between caves and was calculated using Whittaker's $\beta$ diversity measure, based on the presence/absence of crustacean species. These tests were performed with PAST (PAlaeontological STatistics), ver. 0.93 (Hammer et al., 2002).

A matrix was created for the biological data set based on the presence/absence of crustacean species. Then, the same matrix was transformed using the Bray-Curtis similarity index in order to evaluate the degree of similarity among samples. The latter analysis was performed with PRIMER 6 (Primer-E Ltd, Plymouth Marine Laboratory, UK) (Clarke and Warwick, 2001).

\section{Results}

\section{Water chemistry}

All physico-chemical parameters differed between and within caves throughout the year (Table 2). The dripping water from UC, VC and CC had no significant contamination from the surface. The highest standard deviations of $\mathrm{Al}, \mathrm{Cr}, \mathrm{Fe}, \mathrm{NO}_{2}^{-}$and $\mathrm{COD}$ values were found in $\mathrm{CC}$ drips.
The $\mathrm{pH}$ was slightly alkaline in all samples; the highest $\mathrm{pH}$ and highest temperature variations were measured in $\mathrm{UC}$, at sites 3 and 1. Seasonal variation in the temperature of drips located close to the cave entrances appeared to be strongly affected by the external climatic conditions (e.g., site 1 in UC). With regard to electrical conductivity, the highest amplitude was registered in CC, where spatial and temporal variations were observed; in most cases, the samples from sites 1,2 and 3 showed low electrical conductivity, measured in winter and early spring, whereas the same sites revealed high electrical conductivity during summer and autumn; at the other sites (4-9), high electrical conductivity values were measured during the entire year. The greatest constancy of $\mathrm{pH}$, temperature and electrical conductivity was measured in LC.

\section{Fauna composition}

The 350 biological samples collected during the sampling period contained 1726 individuals. The following major taxonomic groups were identified: Oligochaeta, Nematoda, Cyclopoida, Harpacticoida, Ostracoda, Collembola, Acarina, Amphipoda, Isopoda, Gastropoda and Insecta larvae (mainly Diptera Chironomidae). The total number of taxonomic groups varied among the five investigated caves from 8 to 11 (Table 3 ). Taxa composition (at higher taxonomic rank) and abundance varied within and between caves (Table 3 ).

The distribution of taxa with the highest number of individuals $(N>3)$ and high frequency was analyzed for UC, LC and CC. In UC (Fig. 3a), the poor fauna at site 1 was represented by insect larvae (chironomids) in June and July. Site 3 was the richest, with a constant high number of harpacticoids in almost all months (except April and September). In LC (Fig. 3b), insect larvae were more abundant at sites 1,2 and 6. Harpacticoids were encountered in high number at almost all sites. The harpacticoids were the best-represented group at site 5, except for October when amphipods were dominant. Site 6 was represented only by insect larvae in October. In CC (Fig. 3c), harpacticoids and cyclopoids were represented in almost all sites, with high abundance at sites 3, 6 and 7 . Ostracods were mainly distributed at site 7 , except in March and April, when they were also present at sites 3 and 4.

The spatial and temporal variation of taxa related to the physico-chemical parameters of the dripping water was examined for $\mathrm{UC}, \mathrm{VC}$ and $\mathrm{CC}$. In the resulting plot (Fig. 4), major taxonomic groups and sites were ordered in the taxa-environment space. The cumulative percentage variance of the taxa-environment relationship was $80.90 \%$ for the first two canonical axes. The CCA axis 1 was strongly correlated with increasing electrical conductivity and decreasing $\mathrm{pH}$, and accounted for $54.56 \%$ of the taxa-environment relationship. The best-represented taxa (harpacticoids, insect larvae and nematodes) are distributed along this axis. Axis $2(26.38 \%)$ is a gradient of decreasing temperature and increasing $\mathrm{Al}$, being related 
Table 2. Physico-chemical features of dripping water in the selected caves during the one-year sampling period ("--" = not measured) (for cave abbreviations see Table 1).

\begin{tabular}{|c|c|c|c|c|c|}
\hline Parameter/cave & $\mathrm{UC}$ & $\mathrm{VC}$ & $\mathrm{LC}$ & $\mathrm{CC}$ & $\mathrm{DC}$ \\
\hline \multicolumn{6}{|l|}{ pH } \\
\hline Mean & 8.70 & 8.36 & 8.58 & 8.49 & 8.35 \\
\hline SD & 0.35 & 0.23 & 0.26 & 0.22 & 0.19 \\
\hline Min & 7.90 & 7.80 & 8.00 & 7.80 & 8.00 \\
\hline $\operatorname{Max}$ & 9.60 & 8.90 & 9.00 & 8.90 & 8.80 \\
\hline \multicolumn{6}{|l|}{$\mathrm{EC}\left(\mu \mathrm{S} . \mathrm{cm}^{-1}\right)$} \\
\hline Mean & 256.13 & 380.84 & 180.61 & 265.31 & 281.70 \\
\hline SD & 73.97 & 60.49 & 28.16 & 85.53 & 67.77 \\
\hline Min & 118.00 & 273.00 & 132.00 & 71.00 & 178.00 \\
\hline $\operatorname{Max}$ & 437.00 & 506.00 & 279.00 & 482.00 & 382.00 \\
\hline \multicolumn{6}{|l|}{$T\left({ }^{\circ} \mathrm{C}\right)$} \\
\hline Mean & 9.98 & 11.80 & 8.77 & 10.62 & 10.05 \\
\hline SD & 3.17 & 2.09 & 0.97 & 1.92 & 1.48 \\
\hline Min & 4.70 & 9.00 & 6.50 & 7.80 & 4.90 \\
\hline Max & 18.20 & 23.60 & 11.40 & 15.7 & 12.6 \\
\hline \multicolumn{6}{|l|}{$\mathrm{Al}\left(\mathrm{mg} . \mathrm{L}^{-1}\right)$} \\
\hline Mean & 0.42 & 0.11 & - & 0.54 & - \\
\hline SD & 0.71 & 0.07 & - & 0.73 & - \\
\hline Min & 0.02 & 0.02 & - & 0.00 & - \\
\hline Max & 2.63 & 0.32 & - & 2.68 & - \\
\hline \multicolumn{6}{|l|}{$\mathrm{Cr}\left(\mathrm{mg} . \mathrm{L}^{-1}\right)$} \\
\hline Mean & 0.01 & 0.01 & - & 0.01 & - \\
\hline $\mathrm{SD}$ & 0.02 & 0.01 & - & 0.02 & - \\
\hline Min & 0.00 & 0.00 & - & 0.00 & - \\
\hline $\operatorname{Max}$ & 0.06 & 0.06 & - & 0.09 & - \\
\hline \multicolumn{6}{|l|}{$\mathrm{Fe}\left(\mathrm{mg} . \mathrm{L}^{-1}\right)$} \\
\hline Mean & 0.63 & 0.31 & - & 2.94 & - \\
\hline $\mathrm{SD}$ & 0.73 & 0.63 & - & 6.21 & - \\
\hline Min & 0.19 & 0.03 & - & 0.01 & - \\
\hline Max & 2.81 & 4.00 & - & 21.70 & - \\
\hline \multicolumn{6}{|l|}{$\mathrm{NO}_{2}^{-}\left(\mathrm{mg} \cdot \mathrm{L}^{-1}\right)$} \\
\hline Mean & 0.25 & 0.46 & - & 0.44 & - \\
\hline SD & 0.24 & 0.35 & - & 1.15 & - \\
\hline Min & 0.05 & 0.05 & - & 0.05 & - \\
\hline $\operatorname{Max}$ & 0.74 & 1.14 & - & 4.00 & - \\
\hline \multicolumn{6}{|l|}{$\mathrm{COD}\left(\mathrm{mg} \cdot \mathrm{L}^{-1}\right)$} \\
\hline Mean & 9.21 & 6.95 & - & 8.17 & - \\
\hline SD & 10.57 & 10.61 & - & 12.08 & - \\
\hline Min & 1.60 & 0.10 & - & 1.00 & - \\
\hline Max & 38.30 & 45.80 & - & 51.40 & - \\
\hline
\end{tabular}

to oligochaetes and ostracods. The samples where high electrical conductivity was measured are grouped in the right part of the plot. Two samples are isolated in the left part of the plot: UC in January, due to the lowest temperature measured there $\left(5.8^{\circ} \mathrm{C}\right)$, and $\mathrm{CC}$ in July when a high value of $\mathrm{Fe}$ was measured (14.6 mg. $\left.\mathrm{L}^{-1}\right)$ and many insect larvae were found.

\section{Crustacea}

The crustaceans contributed the most to the total biodiversity of the study area, being highly diversified at all taxonomic levels: seven families, 12 genera and 15 species (Table 4). The sampling completeness, based on 11 crustacean species and 46 samples collected every month from all five caves, was tested (Fig. 5). The SAC did not reach an asymptote. Twenty-seven samples were sufficient to find eight species, while about 10 species were found after collecting 44 samples out of 46 . Even if the sampling continues since 2008, no new species were found.

The proportion of species richness varied within and between caves. $\alpha$-Diversity was the highest in CC and DC. $\beta$-Diversity was higher between the caves from Crişul Negru Basin (1.54) compared with the values in caves from the Crişul Repede Basin (1.21) (Table 5).

Among crustaceans, the harpacticoid copepods dominated in terms of both species richness (seven species) and total number of crustacean individuals (74\%). Species known to be adapted for life in subterranean habitats (i.e., stygobionts) were found: among the Harpacticoida, Parastenocaris sp. (in CC), the widely distributed Spelaeocamptus spelaeus (Chappuis, 1925) and Maraenobiotus brucei carpathicus Chappuis 1928 (in UC, VC and CC); among the Cyclopoida, Speocyclops troglodytes (Chappuis, 1923) (in VC), Acanthocyclops sp. (in UC, LC, CC and DC); and among the Amphipoda, Niphargus andropus Schellenberg, 1940 (in LC and CC).

The epigean crustacean fauna was represented by species widely distributed in all the caves: Bryocamptus (Rheocamptus) caucasicus Borutzky, 1930, or species found in only one cave: Maraenobiotus vejdovskyi vejdovskyi Mrazek, 1893, Diacyclops bisetosus (Rehberg, 1880) (in VC) and Paracyclops fimbriatus (Fischer, 1853) (in UC). The epigean Candona neglecta Sars, 1887 was the only ostracod identified in CC and DC.

The spatial and temporal dynamics of epigean and hypogean crustaceans along the physico-chemical gradients are defined in Figure 6. The two axis of the CCA accounted for $80.89 \%$ of the total variance. The first axis is a gradient of increasing temperature, while the second axis is a gradient of decreasing electrical conductivity and $\mathrm{pH}$. The first axis $(52.35 \%)$ is related to B. caucasicus, C. neglecta and P.fimbriatus, suggesting that their distribution is influenced by temperature and $\mathrm{pH}$; the second axis $(28.54 \%)$ is related mainly to the hypogean species $S$. spelaeus and M. b. carpathicus, whose distribution might be influenced by electrical conductivity.

The spatial distribution pattern within and between caves based on Bray-Curtis (BC) similarity analysis (Fig. 7) showed three main clusters. Clustered at the lowest level of similarity $(40 \%)$ are stations from the same cave (CC); these stations are about $8 \mathrm{~m}$ apart and share one endemic hypogean harpacticoid ( $S$. spelaeus). The next cluster (68\%) grouped sites from VC and LC caves in the same basin but about $15 \mathrm{~km}$ apart, sharing another endemic harpacticoid, Bryocamptus sp. 1. The third cluster grouped, at $46 \%$ similarity, sites from all caves based on the widely distributed harpacticoids $B$. caucasicus and S. spelaeus. 
Table 3. Relative abundance (A\%) and relative frequency ( $\mathrm{F} \%$ ) of major taxonomic groups recorded in the five caves during the one-year sampling period.

\begin{tabular}{|c|c|c|c|c|c|c|c|c|c|c|}
\hline & \multicolumn{2}{|c|}{$\mathrm{UC}$} & \multicolumn{2}{|c|}{$\mathrm{VC}$} & \multicolumn{2}{|c|}{$\mathrm{LC}$} & \multicolumn{2}{|c|}{$\mathrm{CC}$} & \multicolumn{2}{|c|}{$\mathrm{DC}$} \\
\hline & $\overline{\mathrm{A} \%}$ & $\mathrm{~F} \%$ & $\overline{\mathrm{A} \%}$ & $\mathrm{~F} \%$ & $\mathrm{~A} \%$ & $\mathrm{~F} \%$ & $\mathrm{~A} \%$ & $\mathrm{~F} \%$ & $\overline{\mathrm{A} \%}$ & $\mathrm{~F} \%$ \\
\hline Oligochaeta & 4.52 & 19.35 & 1.67 & 4.90 & 2.62 & 15.49 & 6.47 & 18.37 & 4.29 & 6.67 \\
\hline Acarina & 0.85 & 3.23 & 0.32 & 0.98 & 2.82 & 16.90 & 3.11 & 11.22 & 0.00 & 0.00 \\
\hline Amphipoda & 0.85 & 3.23 & 0.00 & 0.00 & 3.66 & 19.72 & 3.13 & 7.14 & 0.00 & 0.00 \\
\hline Isopoda & 0.00 & 0.00 & 0.00 & 0.00 & 0.00 & 0.00 & 0.47 & 2.04 & 2.86 & 2.22 \\
\hline Cyclopoida & 4.80 & 12.90 & 7.00 & 15.69 & 2.68 & 14.08 & 24.67 & 27.55 & 8.57 & 6.67 \\
\hline Harpacticoida & 52.54 & 54.84 & 64.47 & 34.31 & 31.35 & 53.52 & 29.14 & 36.73 & 25.71 & 20.00 \\
\hline Ostracoda & 0.00 & 0.00 & 0.00 & 0.00 & 0.00 & 0.00 & 10.09 & 12.24 & 1.43 & 2.22 \\
\hline Collembola & 4.24 & 19.35 & 23.67 & 35.29 & 11.96 & 36.62 & 9.52 & 16.33 & 24.29 & 22.22 \\
\hline Insect larvae & 30.23 & 29.03 & 1.27 & 2.94 & 42.96 & 15.49 & 6.10 & 7.14 & 2.86 & 2.22 \\
\hline Gastropoda & 0.00 & 0.00 & 0.64 & 0.98 & 0.00 & 0.00 & 0.61 & 3.06 & 0.00 & 0.00 \\
\hline Nematoda & 1.98 & 6.45 & 0.95 & 1.96 & 1.95 & 14.08 & 6.68 & 16.33 & 30.00 & 11.11 \\
\hline
\end{tabular}

\section{Discussion}

The present study focused on the spatial and temporal structure of invertebrate communities in the unsaturated zone of the karst and revealed a patchy distribution within and between caves at different scales.

The heterogeneous distribution of the fauna inhabiting the ground-water habitats reflects biotic and abiotic interactions that took place from the microscale to megascale during historical times (Gibert et al., 1994, 2009). Ground-water habitats are comparatively more conservative than aquatic surface habitats due to their environmental stability. Despite the old conception of ground-water as a species-poor environment, it has been demonstrated that its species richness is greater than formerly assumed and that the fauna (mainly invertebrates) is unexpectedly diverse and unique (Botoşăneanu, 1986; Juberthie and Decu, 1994, 1998, 2001; Gibert et al., 1994, 2009; Stoch, 1995; Juberthie, 2000; Galassi, 2001; Gibert and Deharveng, 2002; Galassi et al., 2009).

\section{$\alpha$ - and $\beta$-diversity}

The water percolating through the unsaturated karst harbors a wide range of organisms, from surface or soil species to highly specialized subterranean fauna (Pipan, 2005). Our study supports this observation by demonstrating the presence of five higher taxa with epigean and hypogean species common in all five caves: oligochaetes, nematodes, cyclopoids, harpacticoids and insects. Their presence indicates biological activity in the network of fissures of the unsaturated karst, where animals move by both active and passive dispersal.

At a larger scale, the contribution of both $\alpha$ - and $\beta$-diversity to total diversity of the area increased with spatial scale, from north to south: from the Crişul Repede Basin (the lowest $\beta$-diversity) (UC, VC and LC) toward the Crişul Negru Basin (the highest $\beta$-diversity) (CC and DC).

Gibert and Deharveng (2002) and Malard et al. (2009) sustain that ground-water diversity is a consequence of differences recorded between sites rather than within-site diversity. Our results show considerable differences both within and between caves. All recorded major taxonomic groups and species have different distribution inside caves and some are found at only one sampling site (i.e., Bryocamptus sp. 1, S. troglodytes, P. fimbriatus). Also crustacean community composition varied within caves and over a larger scale, as confirmed by Bray-Curtis similarity analysis.

The community assemblages from the dripping water in the investigated caves are characterized by high diversity but few individuals. Low numbers of individuals in dripping water were also mentioned by Pipan and Brancelj (2001) in a study that compared different subterranean habitats (i.e., drips, basins on calcareous sinter, and puddles on clay), and by Moldovan et al. (2007) in drips from caves.

The crustaceans contribute considerably to species diversity of dripping water communities, being diversified at both taxonomic and ecological levels. Our findings confirm the patterns previously observed in various ground-water habitats from the temperate regions (Ferreira et al., 2007). Crustaceans are the dominant group in ground-water and account for $71.9 \%$ and $80.3 \%$ of the species and records, respectively, in the European database (Malard et al., 2009). In the present study, crustaceans represent $73 \%$ from the total fauna. Each cave holds between five and eight species in drips, and the highest diversity was recorded in $\mathrm{CC}$, with eight crustacean species. The trend of the species accumulation curve for crustaceans assumes that a major part of the total diversity was covered by spatial and temporal samplings.

Among the variety of ground-water habitats, the unsaturated karstic zone is known to be the richest in stygobiotic copepods (Pipan and Brancelj, 2004a; Pipan and Culver, 2007a; Galassi et al., 2009). The copepods are the most abundant and frequent in the unsaturated karstic zone of our study area, except in LC. This result is supported by their high specialization, compared with other groups, for narrow spaces (Pipan and Brancelj, 2001, 2004a, 2004b; Pipan, 2005; Camacho et al., 2006; 

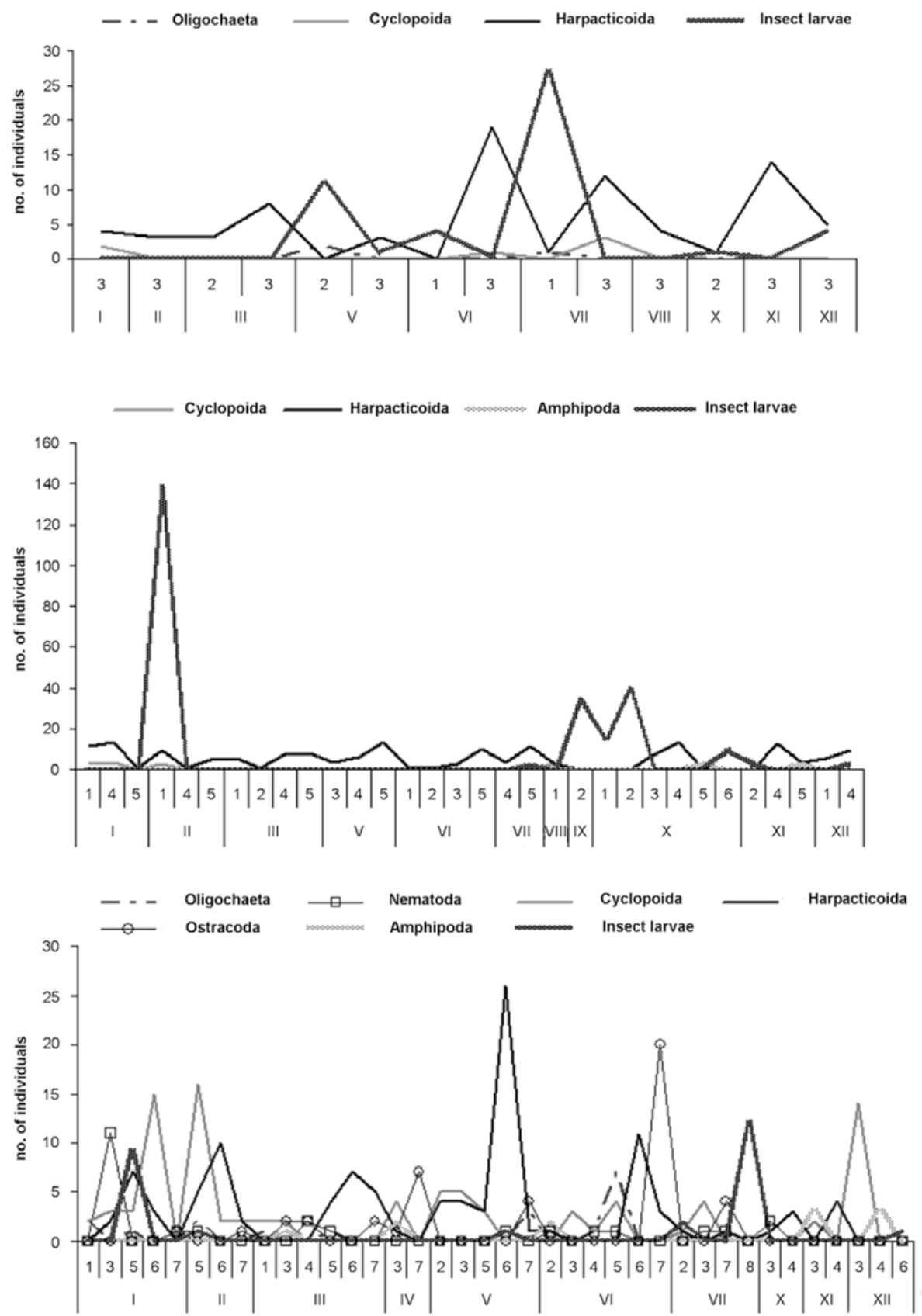

Fig. 3. Number of individuals $(N>3)$ of major taxa recorded in UC (a), LC (b) and CC (c) over the one-year sampling period; sampling month: I-XII; site number: $1-8$.

Moldovan et al., 2007). The copepods in dripping water are mostly represented by members of the families Canthocamptidae and Parastenocarididae (Harpacticoida) and of the Cyclopidae (Cyclopoida). These are the most successful groups, together with the malacostracans, in colonizing inland ground-water (Galassi, 2001; Boxshall and Defaye, 2008; Galassi et al., 2009). This reflects their wide range of morphological (small size, eye loss), physiological (increased lifespan, low fecundity) and ecological (various trophic niches) features. They are "preadapted" (Galassi et al., 2009) to subterranean environments and hence were able to invade and colonize repeatedly the patchy habitats of the ground-water.
Our results support the view that habitat physicochemical heterogeneity and isolation of microhabitats are determinants for copepod diversity in terms of species richness (Galassi et al., 2009). The most abundant and frequent fraction of the copepods is composed of species with a local distribution. Nonetheless, the significant components of the unsaturated zone are species that display an evident morphology (such as Acanthocyclops sp., S. spelaeus, Parastenocaris sp.) of true hypogean inhabitants: appendage reductions, small-sized body. S. spelaeus is endemic to the Apuseni Mountains and is widespread in caves of one massif of these mountains (Fiers and Moldovan, 2008). S. troglodytes is known 


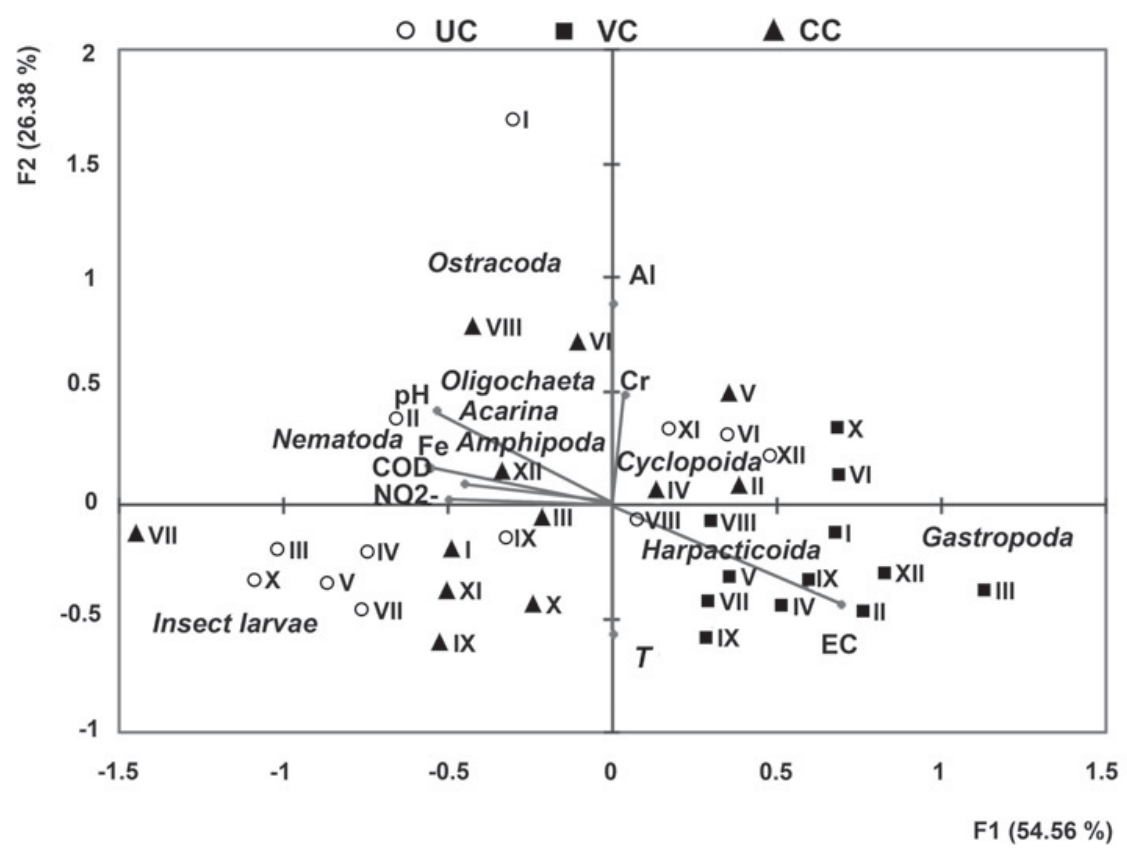

Fig. 4. CCA based on the total number of major taxa/month and the mean values of the physico-chemical parameters measured in UC, VC and CC over the one-year sampling period; sampling month: I-XII; $T$ - temperature, EC - electrical conductivity, COD - chemical oxygen consumption.

from Romania only from the Pădurea Craiului Mountains (Damian-Georgescu, 1963; Pleşa, 1985; Iepure, 2007; Moldovan et al., 2007). Two of the new species belong to two highly specious ground-water genera, Parastenocaris (in CC) and Acanthocyclops (in UC, LC, CC and DC).

At a small scale, species are presumed to interact and compete for similar limiting resources (Gray, 2000); to reduce competition between species, they will use different parts of the habitat (Whittaker, 1972). This view was supported particularly in $\mathrm{CC}$, where species with wide ecological valence (B. caucasicus, S. spelaeus and Acanthocyclops sp.) did not interfere with the distribution of more specialized species (M.b. carpathicus, Parastenocaris sp.). Ostracods - attributable to the species C. neglecta - are represented in high numbers in CC and by only a single individual in DC; this is a common species with a Holarctic distribution. The occurrence of this epigean ostracod in dripping water samples is probably due to seepage from the surface.

Among other fauna groups, oligochaetes and nematodes were frequently recorded and present in relatively high numbers in all caves. Their presence was already assessed for UC and VC (Moldovan et al., 2007) but also for other cave systems (Pipan and Brancelj, 2001; Pipan and Culver, 2005; Camacho et al., 2006; Pipan et al., 2008). The insect larvae are represented mainly by chironomids, and their higher abundance in LC can be related to the more direct inflow of water from the surface inside the cave, and therefore a direct input of surface species (especially chironomids, but also the amphipod Gammarus balcanicus Schäferna, 1922). When high numbers of chironomid larvae and gammarids typical for moist soil and vegetation are present, few or no hypogean species occur in LC. This can be related more to direct discharge of meteoric water underground.

The presence of four new species (Parastenocaris sp., Bryocamptus sp. 1, Bryocamptus sp. 2 and Acanthocyclops sp.) (taxonomic descriptions in progress) and of six endemics supports the observation that cracks and fissures from the unsaturated zone harbor numerous undiscovered species (Pipan et al., 2006; Culver and Pipan, 2007). These species are high contributors to both $\alpha$ - and $\beta$-diversity and consequently increase the conservation value of the caves and of the karstic area of the Pădurea Craiului Mountains. The presence of many copepods and numerous endemics in a country at $45^{\circ}$ northern latitude can be explained by the patchy distribution of limestone in the Carpathian Mountains. This leads to small continental islands among non-karstic areas, which function as natural barriers to hypogean migration and allow the radiation of lineages (Moldovan et al., 2005).

\section{Spatial and temporal distribution patterns and relation to environmental parameters}

The meroclimate, and the regional and geological conditions can significantly influence the variation of physico-chemical parameters inside caves (Musgrove and Banner, 2004). In the caves studied here, the measured physical and chemical parameters of the water varied spatially (between and within caves) and temporally, 
Table 4. List and number of identified taxa in the investigated caves (* - endemic species; bold - hypogean species).

\begin{tabular}{|c|c|c|c|c|c|}
\hline & $\mathrm{UC}$ & $\mathrm{VC}$ & $\mathrm{LC}$ & $\mathrm{CC}$ & $\overline{\mathrm{DC}}$ \\
\hline Species & \multicolumn{5}{|c|}{ No. of individuals } \\
\hline \multicolumn{6}{|l|}{ HARPACTICOIDA } \\
\hline \multicolumn{6}{|l|}{ Fam. Canthocamptidae } \\
\hline Bryocamptus (Rheocamptus) caucasicus Borutzky 1930 & 51 & 65 & 96 & 16 & 3 \\
\hline Bryocamptus (Rheocamptus) sp. $1^{*}$ & - & - & 1 & - & \\
\hline Bryocamptus (Rheocamptus) sp. 2* & 1 & - & 1 & - & \\
\hline Maraenobiotus vejdovskyi vejdovskyi Mrazek, 1893 & - & 1 & - & - & \\
\hline Maraenobiotus brucei carpathicus Chappuis 1928 & 2 & 2 & - & 30 & \\
\hline Spelaeocamptus spelaeus (Chappuis 1925)* & 6 & - & 16 & 34 & \\
\hline \multicolumn{6}{|l|}{ Fam. Parastenocarididae } \\
\hline Parastenocaris sp.* & - & - & - & 24 & \\
\hline Harpacticoid copepodids (indet.) & 14 & 118 & 48 & 6 & \\
\hline Total number of individuals & 74 & 186 & 162 & 110 & 18 \\
\hline Total number of species & 4 & 3 & 4 & 4 & 2 \\
\hline
\end{tabular}

Cyclopoida

Fam. Cyclopidae

Acanthocyclops sp.*

Speocyclops troglodytes (Chappuis 1923)

Diacyclops bisetosus (Rehberg 1880)

Paracyclops fimbriatus (Fischer 1853)

Cyclopoid copepodids (indet.)

Total number of individuals

Total number of species

AMPHIPODA

Fam. Gammaridae

Gammarus balcanicus Schäferna 1922

Fam. Niphargidae

Niphargus andropus Schellenberg 1940*

Juveniles (indet.)

Total number of individuals

Total number of species

1

$-$

4

1

6

2

1

-
-
1
1

OSTRACODA

Fam. Candonidae

Candona neglecta Sars 1887

Juveniles (indet.)

Total number of individuals

ISOPODA

Fam. Mesoniscidae

Mesoniscus graniger (Frivaldsky, 1865) 


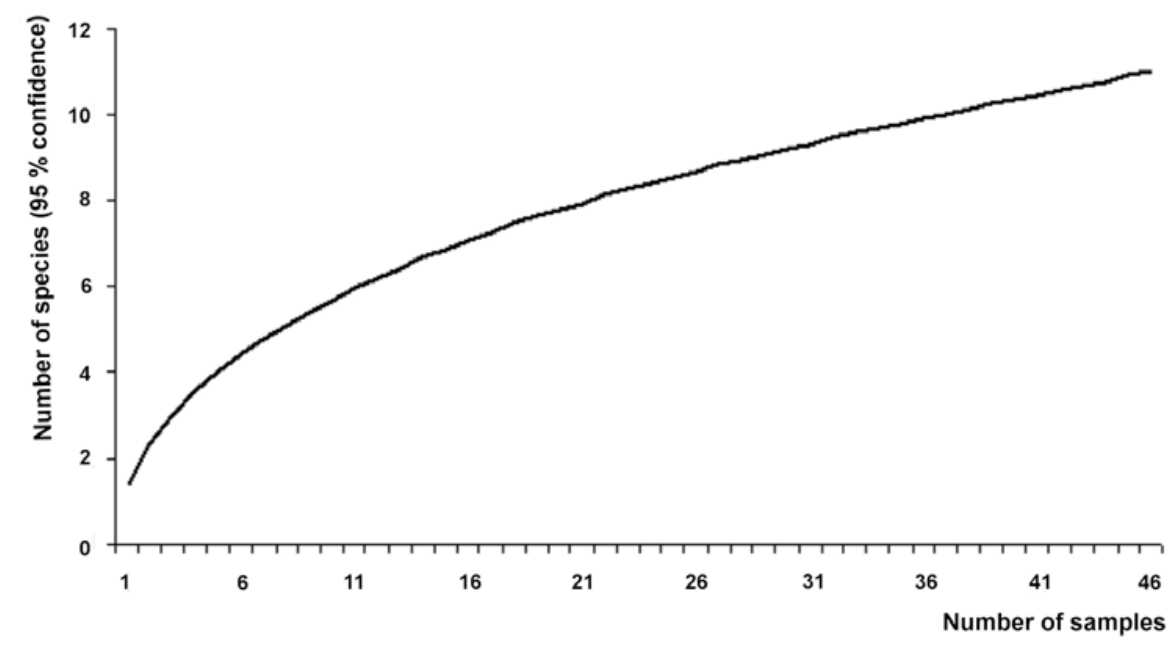

Fig. 5. Crustacean species accumulation curve based on the Mao-Tau procedure.

Table 5. Shannon-Wiener index $(H)$ and Whittaker's $\beta$-diversity measure of crustaceans in the investigated caves, CR - Crişul Repede Basin, CN - Crişul Negru Basin.

\begin{tabular}{|c|c|c|c|c|c|c|}
\hline $\begin{array}{l}\text { Basin } \\
\beta\end{array}$ & $\begin{array}{l}\text { CR } \\
1.21\end{array}$ & & & $\begin{array}{l}\mathrm{CN} \\
1.54\end{array}$ & & $\begin{array}{c}\mathrm{CR} \text { and } \mathrm{CN} \\
1.33\end{array}$ \\
\hline Cave & $\mathrm{UC}$ & VC & $\mathrm{LC}$ & $\mathrm{CC}$ & $\mathrm{DC}$ & \\
\hline$H$ & 0.88 & 0.60 & 1.01 & 1.85 & 1.03 & \\
\hline
\end{tabular}

individuals were recorded there. In LC, the spatial distribution of harpacticoids was constant, with high population densities at almost all sites. This might be explained by the low variations in electrical conductivity and temperature. Amphipods, mainly G. balcanicus, were sampled from only two sites, which were characterized by fast infiltration pathways of the water. In $\mathrm{CC}$, the distribution of almost all the major taxonomic groups was very heterogeneous, with no observable spatial trends. One exception was the harpacticoids, which preferred sites with low yearly variations in electrical conductivity, as in the previous cave.

Paran et al. (2005) and Dole-Olivier et al. (2009) reported that water chemistry only minimally influences faunal distributions. According to Pipan (2005), Pipan et al. (2006) and Moldovan et al. (2007), certain copepod species preferred high conductivity, high temperature and a high concentration of different ions. In our study, electrical conductivity was also the significant factor that influenced taxa composition and distribution: (1) more hypogean harpacticoids were present at sites with high electrical conductivity; (2) more epigean species (cyclopoids and harpacticoids) were present at sites with higher variations of electrical conductivity and temperature. At the species level, two hypogean harpacticoids (M. b. carpathicus and S. spelaeus) were related to high electrical conductivity $\left(200-350 \mu \mathrm{S} . \mathrm{cm}^{-1}\right)$. Such high electrical conductivity indicates lengthier water residence times, underlining that the distribution of hypogean species is influenced by the rock porosity and the available habitats.
$\mathrm{pH}$, dissolved metals, nitrite and chemical oxygen consumption were related mainly with oligochaetes, nematodes, cyclopoids, amphipods and mites, but the effects were not statistically significant. The distributions of the epigean B. caucasicus, $P$. fimbriatus and C. neglecta are influenced by temperature, the first one being found in samples with wide temperature values $\left(3.7-12.1^{\circ} \mathrm{C}\right)$, the others being related to high temperatures $\left(10.0-14.5^{\circ} \mathrm{C}\right)$.

A temporal trend was observed only for insect larvae, with abundance peak during summer months, except in LC, where the peak was recorded in late winter. No seasonal pattern was discernible for other taxa; rather than being linked to seasons, the assemblages were related more to physico-chemical features. These, in turn, are potentially influenced by surface parameters.

Copepod composition and distribution are mentioned to be influenced by the amount of precipitation (Pipan and Brancelj, 2001; Pipan, 2005), and the distribution of narrow distributed copepod species to be related to the water chemistry (i.e., sodium, nitrate and potassium) (Pipan, 2005; Pipan et al., 2006). We found no significant correlation between the number of crustacean species from dripping water and precipitation. Also, there was no significant correlation between taxa distribution and water chemistry (i.e., dissolved metals, nitrite and chemical oxygen consumption).

Differences in $\alpha$-diversity (within caves) and $\beta$-diversity (between hydrographic basins) in caves from the Pădurea Craiului Mountains integrate the results on the spatial heterogeneous distribution of taxa in the vadose zone correlated with life strategy, hydrological dynamics and variations in the water physico-chemical parameters. The heterogeneous distribution of aquatic fauna in this ecosystem was also mentioned in previous studies (Pipan and Brancelj, 2001; Sket et al., 2004; Pipan, 2005; Pipan and Culver, 2005; Moldovan et al., 2007). A temporal trend was observed only for epigean species (chironomids), while the hypogean representatives were confined to specific sites or galleries within the caves. The narrow spatial distribution of hypogean species was also observed 


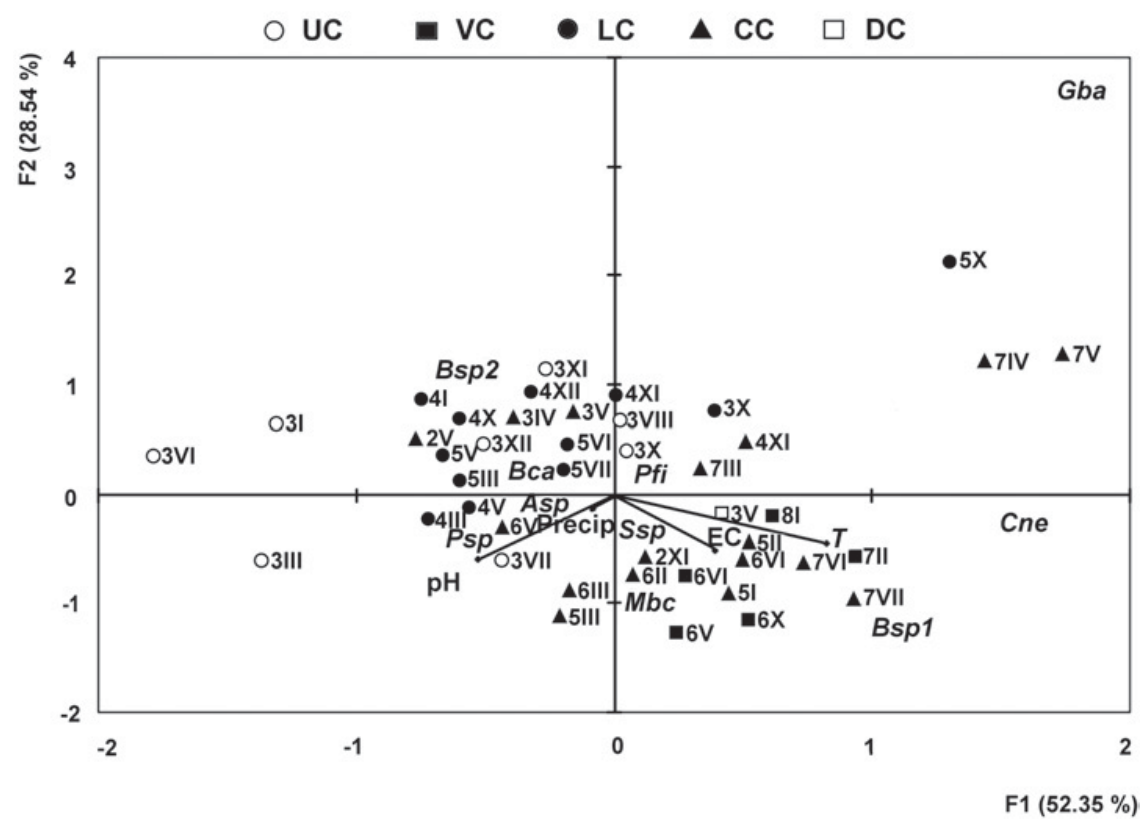

Fig. 6. CCA based on crustacean species, physico-chemical parameters (pH, $T$ and EC) and precipitation (Precip.) registered in the five caves over the one-year sampling period: Bca-B. caucasicus; Bsp1-Bryocamptus sp. 1; Bsp2-Bryocamptus sp. 2 ; Mbc - M. b. carpathicus; Ssp - S. spelaeus; Psp - Parastenocaris sp.; Asp - Acanthocyclops sp.; Pfi - P. fimbriatus; Cne - C. neglecta; Gba G. balcanicus; sampling month: I-XII; $T$ - temperature, EC - electrical conductivity.

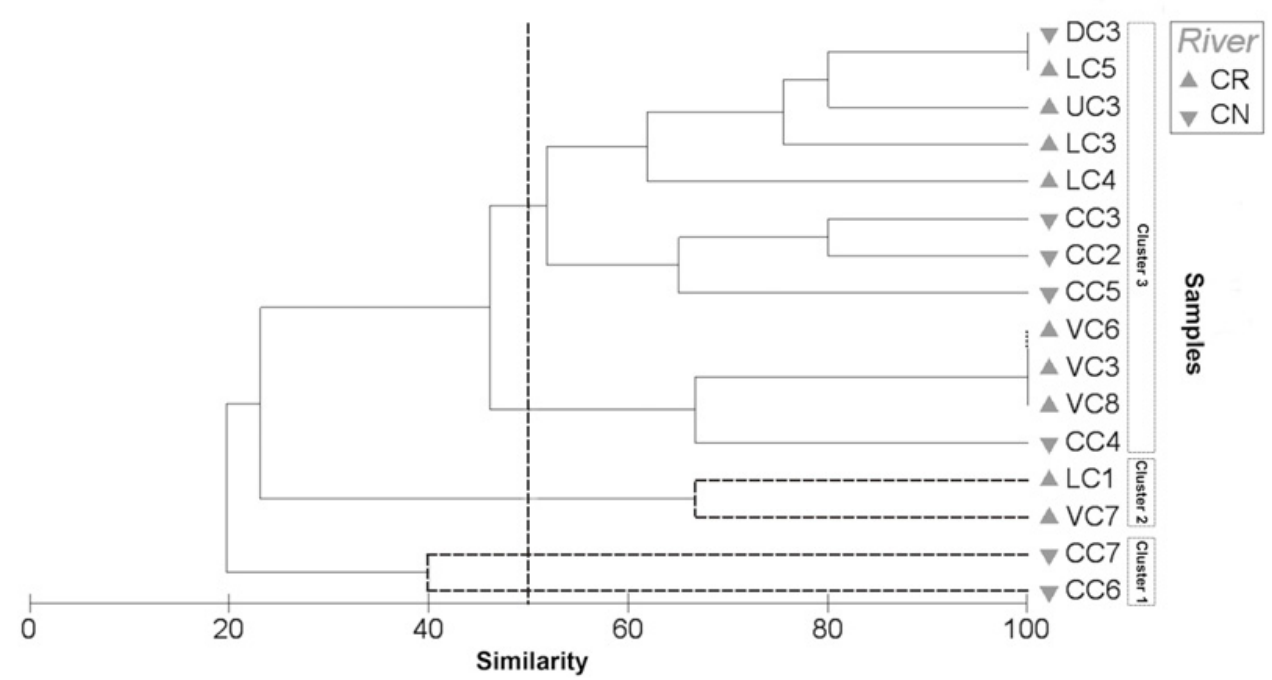

Fig. 7. Bray-Curtis dendrogram based on the presence of crustacean species in the investigated caves over the one-year sampling period. Site number: 1-8; CR - Crişul Repede River; CN - Crişul Negru River.

by Brancelj (2002), Pipan (2005) and Moldovan et al. (2007).

The present study emphasizes the importance of electrical conductivity and drip constancy in shaping the distribution and composition of hypogean crustacean species, as an indirect measure of rock porosity, habitat availability and water residence time in karst. In contrast, epigean species are related to high variation in physico-chemical parameters (temperature and electrical conductivity), underlining their transitory status within the vadose zone.

Acknowledgements. The Crisuri Water Branch is thanked for the precipitation data. We thank Viorel Lascu for cave access and help in the field, and the administrations of the Ungurului 
(Şuncuiuş Council) and the Vadu-Crişului (the "Țării Crişurilor" Museum) caves. We thank Michael Stachowitsch for the English corrections of the manuscript. This study was financially supported by The National University Research Council, Grant IDEI_1150, Bilateral cooperation grant no. 72/2008 and SYNTHESYS (BE-TAF 4681), all three granted to OTM. Special thanks go to Régis Céréghino and the anonymous reviewers for improving the manuscript.

\section{References}

Bobić M., 2003. Microfauna of percolating waters in Lazareva Cave (East Serbia, YU). In: Proceeding of 4th Symposium on Karst Protection, Beograd, 101-104.

Botoşăneanu L. (ed.), 1986. Stygofauna Mundi, E.J. Brill and Dr W. Backhuys, Leiden, The Netherlands, 740 p.

Bou C., 1979. La grotte Trois-Cloches et son intérêt scientifique. Bull. Féd. tarnaise Spéléo-Archéol., 16, 3-10.

Boxshall G. and Defaye D., 2008. Global diversity of copepods (Crustacea: Copepoda) in freshwater. Hydrobiologia, 595, 195-207.

Brancelj A., 2002. Microdistribution and high diversity of Copepoda (Crustacea) in a small cave in central Slovenia. Hydrobiologia, 477, 59-72.

Camacho A.I., Valdecasas A.G., Rodriguez J., Cuezva S., Lario J. and Sanchez-Moral S., 2006. Habitat constraints in epikarstic water of an Iberian Peninsula cave system. Ann. Limnol. - Int. J. Lim., 42, 127-140.

Clarke K.R. and Warwick R.M., 2001. Change in marine communities: an approach to statistical analysis and interpretation, Plymouth Marine Laboratory, Plymouth.

Colwell R.K., 2005. EstimateS: statistical estimation of species richness and shared species from samples Version 7.5. User's Guide and application published at http://purl.oclc.org/ estimates.

Colwell R.K., Mao C.X. and Chang J., 2004. Interpolating, extrapolating and comparing incidence-based species accumulation curves. Ecology, 85, 2717-2727.

Culver D.C. and Pipan T., 2007. Subterranean ecosystems. In: Levin S.A. (ed.), Encyclopedia of biodiversity, Elsevier Academic Press, Amsterdam, 1-19.

Damian-Georgescu A., 1963. Copepoda. Fam. Cyclopidae (forme de apă dulce). Fauna Republicii Populare Romîne, Academia Republicii Socialiste Romînia, Crustacea, 4, 205 p. [In Romanian. Illustrated keys to families, genera, and species.]

Delay B., 1968. Données sur le peuplement de la zone de percolation temporaire. Ann. Spéléolog., 20, 705-716.

Dole-Olivier M.J., Malard F., Martin D., Bure T.L. and Gibert J., 2009. Relationships between environmental variables and groundwater biodiversity at the regional scale. Freshwater Biol., 54, 797-813.

Ferreira D., Malard F., Dole-Olivier M.J. and Gibert J., 2007. Obligate groundwater fauna of France: diversity patterns and conservation implications. Biodiv. Conserv., 16, 567-596.

Fiers F. and Moldovan O.T., 2008. Redescription of Spelaeocamptus spelaeus (Chappuis 1925), a subterranean copepod endemic to the Apuseni Mountains in Romania (Copepoda Harpacticoida). Subt. Biol., 6, 51-64.
Galassi D.M.P., 2001. Groundwater copepods: diversity patterns over ecological and evolutionary scales. Hydrobiologia, 453, 227-253.

Galassi D.M.P., Huys R. and Reid J., 2009. Diversity, ecology and evolution of groundwater copepods. Freshwater Biol., 54, 691-708.

Gibert J. and Deharveng L., 2002. Subterranean ecosystems: a truncated functional biodiversity. BioScience, 52, 473481.

Gibert J., Stanford J., Dole-Olivier M.J. and Ward J.V., 1994. Basic attributes of ground water ecosystems and prospects for research. In: Gibert J., Danielopol D.L. and Stanford J. (eds.), Groundwater ecology, Academic Press, San Diego, CA, 7-40.

Gibert J., Culver D.C., Dole-Olivier M.J., Malard F., Christman M.C. and Deharveng L., 2009. Assessing and conserving groundwater biodiversity: synthesis and perspectives. Freshwater Biol., 54, 930-941.

Gray J.S., 2000. The measurement of marine species diversity, with an application to the benthic fauna of the Norwegian continental shelf. J. Exp. Mar. Biol. Ecol., 250, 23-49.

Hammer Ǿ., Harper D.A.T. and Ryan P.D., 2002. PAST PAlaeontological STatistics, ver. 0.93.

Iepure S., 2007. Cyclopoida Copepoda. In: Moldovan O.T. (ed.), Lista faunistică a României. Specii terestre şi de apa dulce (Checklist of Romania fauna. Terrestrial and freshwater), CristalPrint, Cluj-Napoca, 89-90.

Jones W.K., Culver D.C. and Herman J.S. (eds.), 2004. Proceedings of the Symposium on Epikarst, Shepherdstown, West Virginia, 1-4 October 2003, Karst Waters Institute Special Publication 9, Charles Town, WV, 160 p.

Juberthie C., 2000. The diversity of the karstic and pseudokarstic hypogean habitats in the world. In: Wilkens H., Culver D.C. and Humphreys W.F. (eds.), Ecosystems of the world, 30, Subterranean ecosystems, Elsevier Academic Press, Amsterdam, 17-39.

Juberthie C. and Decu V. (eds.), 1994. Encyclopaedia Biospeleogica I, Société de Biospéléologie, Moulis-Bucarest, $834 \mathrm{p}$.

Juberthie C. and Decu V. (eds.), 1998. Encyclopaedia Biospeleogica II, Société de Biospéléologie, MoulisBucarest, 835-1373.

Juberthie C. and Decu V. (eds.), 2001. Encyclopaedia Biospeleogica III, Société de Biospéléologie, MoulisBucarest, 1374-2294.

Malard F., Boutin C., Camacho A.I., Ferreira D., Michel G., Sket B. and Stoch F., 2009. Diversity patterns of stygobiotic crustaceans across multiple spatial scales in Europe. Freshwater Biol., 54, 756-776.

Mangin A., 1994. Karst hydrogeology. In: Gibert J., Danielopol D.L. and Stanford J. (eds.), Groundwater ecology, Academic Press, San Diego, CA, 43-64.

Moldovan O., Iepure S. and Perşoiu A., 2005. Biodiversity and protection of Romanian karst areas: the example of interstitial fauna. In: Stevanović Z. and Milanović P. (eds.), Water resources \& environmental problems in karst, National Committee of the International Association of Hydrogeologists (IAH) of Serbia and Montenegro, Belgrade, 831-837.

Moldovan O.T., Pipan T., Iepure S., Mihevc A. and Mulec J., 2007. Biodiversity and ecology of fauna in percolating water 
in selected Slovenian and Romanian caves. Acta Carsol., 36, 493-501.

Musgrove M. and Banner J.L., 2004. Controls on the spatial and temporal variability of vadose dripwater chemistry: Edwards Aquifer, central Texas. Geochim. Cosmochim. Acta, 68, 10071020 .

Onac B., 2002. Endokarst - Cave deposits. In: Racoviţă G., Moldovan O. and Onac B. (eds.), The karst of Pădurea Craiului Mountains, Monographic study, Presa Universitară, Cluj-Napoca, 67-77.

Orăşeanu I., 1991. Hydrogeological map of the Pădurea Craiului Mountains (Romania). Theor. Appl. Karstol., 4, 97-127.

Paran F., Malard F., Mathieu J., Lafont M., Galassi D.M.P. and Marmonier P., 2005. Distribution of groundwater invertebrates along an environmental gradient in a shallow water-table aquifer. In: Gibert J. (ed.), Proceedings of an International Symposium on World Subterranean Biodiversity, Villeurbanne, France, 8-10 December 2004, University of Lyon, France, 99-105.

Pipan T., 2005. Epikarst - A promising habitat, ZRC Publishing, Karst Research Institute at ZRC SAZU, Postojna, Ljubljana, $101 \mathrm{p}$.

Pipan T. and Brancelj A., 2001. Ratio of copepods (Crustacea: Copepoda) in fauna of percolation water in six karst caves in Slovenia. Acta Carsol., 30, 257-265.

Pipan T. and Brancelj A., 2003. Fauna of epikarst - Copepoda (Crustacea) in percolation water of karst caves in Slovenia. Ann., Ser. Hist. Nat., 13, 223-228.

Pipan T. and Brancelj A., 2004a. Diversity and peculiarity of epikarst fauna: Case study from six caves in Slovenia (Europe). In: Jones W.K., Culver D.C. and Herman J.S. (eds.), Proceedings of the Symposium on Epikarst, Shepherdstown, West Virginia, 1-4 October 2003, Karst Waters Institute Special Publication 9, Charles Town, WV, 119-126.

Pipan T. and Brancelj A., 2004b. Distribution patterns of copepods (Crustacea: Copepoda) in percolation waters of the Postojnska Jama Cave System (Slovenia). Zool. Stud., 43, 206-210.

Pipan T. and Culver D.C., 2005. Estimating biodiversity in the epikarstic zone of a West Virginia cave. J. Cave Karst Stud., 67, 103-109.
Pipan T. and Culver D.C., 2007a. Epikarst communities: biodiversity hotspots and potential water tracers. Environ. Geol., 53, 265-269.

Pipan T. and Culver D.C., 2007b. Copepod distribution as an indicator of epikarst system connectivity. Hydrogeol. J., 15, 817-822.

Pipan T. and Culver D.C., 2007c. Regional species richness in an obligate subterranean dwelling fauna - epikarst copepods. J. Biogeogr., 34, 854-861.

Pipan T., Blejec A. and Brancelj A., 2006. Multivariate analysis of copepod assemblages in epikarstic waters of some Slovenian caves. Hydrobiologia, 559, 213-223.

Pipan T., Navodnik V., Janžekovič F. and Novak T., 2008. Studies of the fauna of percolation water of Huda Luknja, a cave in isolated karst in northeast Slovenia. Acta Carsol., 37, 141-151.

Pleşa C., 1969. Cercetări asupra periodicităţii reproductive la unele crustacee cavernicole troglobionte, Ph.D. Thesis, Inst. Biologie "Tr. Săvulescu", Bucarest.

Pleşa C., 1985. Conspectul sistematic al Cyclopidelor (crustacee, copepode) cunoscute până în prezent din R.P.R. Studia Univ. Victor Babess - Bolyai, II, 137-150.

Rouch R., 1968. Contribution à la connaissance des Harpacticides hypogés. Ann. Spéléol., 23, 1-167.

Rusu T., 1988. Pe urmele apelor subterane. Carstul din Munţii Pădurea Craiului, Ed. Dacia, Cluj-Napoca, 253 p.

Sket B., Trontelj P. and Žagar C., 2004. Speleobiological characterization of the epikarst and its hydrological neighborhood: its role in dispersion of biota, its ecology and vulnerability. In: Jones W.K., Culver D.C. and Herman J.S. (eds.), Proceedings of the Symposium on Epikarst, Shepherdstown, West Virginia, 1-4 October 2003, Karst Waters Institute Special Publication, 9, Charles Town, WV, 104-113.

Stoch F., 1995. The ecological and historical determinants of Crustacean diversity in groundwaters, or: why are there so many species? Mém. Biospéol., 22, 139-160.

Vălenaş L. and Iurkiewicz A., 1981. Studiu complex al carstului din zona Şuncuiuş-Mișid (Munții Pădurea Craiului), Muzeul Ţării Crişurilor Oradea, Biblioteca Nymphaea, 378 p.

Whittaker R.H., 1972. Evolution and measurement of species diversity. Taxon, 21, 213-251. 